\title{
PERGULATAN KEPENTINGAN POLITIK DALAM RELASI INTER DENOMINASI KRISTEN DI MANADO
}

\author{
POLITICAL INTERESTS IN THE RELATIONSHIP BETWEEN \\ CHRISTIAN DENOMINATION IN MANADO
}

\author{
Muhammad Irfan Syuhudi \\ Balai Penelitian dan Pengembangan Agama Makassar \\ JL. AP. Pettarani, No. 72 Makassar \\ Email: irfansyuhudi@gmail.com
}

Naskah diterima tanggal 12 oktober 2018, Naskah direvisi tanggal 18 Oktoeber 2018, Naskah disetujui tanggal 5 November 2018

\begin{abstract}
Abstrak
Kota Manado sejak dulu identik dengan agama Kristen. Ini disebabkan oleh jumlah penduduk di kota ini kebanyakan menganut agama Kristen. Denominasi Kristen di Manado cukup bervariasi, seperti Protestan, Pantekosta, Bala Keselamatan, dan Karismatik. Dari beragam denominasi tersebut, yang paling banyak pemeluknya adalah Protestan. Tujuan penelitian ini adalah ingin mendeskripsikan dinamika perkembangan denominasi Kristen di Manado, mendeskripsikan pergulatan kepentingan politik dalam relasi inter denominasi Kristen di Manado, serta mendeskripsikan kalangan inter denominasi Kristen mengatasi persoalan di antara mereka. Jenis penelitian ini menggunakan metode kualitatif, dengan penentuan informan secara purposif. Pengumpulan data dilakukan dengan mewawancarai orang-orang yang memahami tema penelitian ini, seperti pendeta, aktivis gereja, tokoh agama Kristen, dan jemaat gereja. Pengumpulan data juga melalui observasi terkait aktivitas umat Kristen, seperti relasi antar inter denominasi serta dunia perpolitikan di Manado. Studi dokumentasi dilakukan untuk memperkuat temuan data lapangan penelitian ini. Analisis penelitian ini menggunakan analisis deskriptif. Temuan penelitian menunjukkan, perkembangan denominasi Kristen di Manado mulai berkembang pasca reformasi, yang ditunjukkan dengan kehadiran beberapa denominasi di kota ini, seperti Protestan, Pantekosta, Bala Keselamatan, dan Kharismatik. Dari sekian denominasi tersebut, denominasi Protestan yang terlihat paling banyak penganutnya, terutama dari Gereja Masehi Injil Minahasa (GMIM).Relasi di kalangan penganut inter denominasi Kristen juga terlihat belum sepenuhnya baik. Masih sering pula terlihat adanya perlakuan diskriminatif denominasi dominan terhadap denominasi kecil, meski sifatnya laten. Dalam panggung politik dan pemerintahan, denominasi Protestan dan Gereja GMIM juga terlihat mendominasi hampir semua bidang.
\end{abstract}

Kata kunci: Kristen, inter denominasi, GMIM, Kota Manado

\begin{abstract}
Manado city has always been synonymous with Christianity. This is due to the large number of people in this city who embrace Christianity. Christian denominations in Manado are quite varied, such as Protestants, Pentecostals, Salvation Army and Charismatics. Of the various denominations, the most widely held are Protestants. The purpose of this study was to describe the dynamics of the development of Christian denominations in Manado, describing the struggle for political interests in Christian inter denomination relations in Manado, and describing Christian inter denominations overcoming the problems between them. This type of research uses qualitative methods, with purposive determination of informants. Data collection was done by interviewing people who understood the theme of this research, such as pastors, church activists, Christian religious leaders, and church congregations. Data collection is also through observation related to Christian activities, such as relations between inter denominations and the world of politics in Manado. Documentation studies were conducted to strengthen the findings of the field research data. This research analysis uses descriptive analysis. The findings of the study show that the development of Christian denominations in Manado began to develop after the reformation, which was demonstrated by the presence of several denominations in this city, such as Protestants, Pentecostals, Salvation Army and Charismatics. Of these denominations, the Protestant denominations that are seen by most adherents,
\end{abstract}


especially from the Minahasa Gospel Church (GMIM). Relations among Christian denominations also do not appear to be fully good. There is also often seen discriminatory treatment of dominant denominations against small denominations, even though they are latent. In the political and government stage, Protestant denominations and the GMIM Church also appear to dominate almost all fields.

Keywords: Christianity, inter denomination, GMIM, Manado City

\section{PENDAHULUAN}

$\mathrm{S}$ ulawesi Utara (Sulut) dan Kota Manado seringkali menjadi percontohan mengenai kerukunan antarumat beragama di Indonesia. Hal ini diperpertegas melalui beberapa penelitian yang membuktikan, daerah ini tergolong aman dari sergapan konflik yang mengatasnakaman kehidupan umat beragama. Pada 2017, Badan Penelitian dan Pengembangan (Litbang) dan Pendidikan dan Latihan (Diklat) Kementerian Agama (Kemenag) Republik Indonesia saat melakukan Survei Nasional menunjukan, indeks Kerukunan Umat Beragama di Sulut tergolong baik. Dari 34 provinsi di Indonesia, daerah yang dijuluki Nyiur Melambai, ini menempati peringkat ketiga dengan mengantongi indeks, 81,0. Urutan pertama ditempati Nusa Tenggara Timur $(83,4)$ dan di urutan kedua Papua, 82,0. Pada tahun sebelumnya, 2011, Balai Litbang Agama Makassar juga menunjukkan indeks kerukunan antarumat beragama di Sulut tinggi, yaitu 0,79.

Bila melihat hasil survei di atas, kerukunan antarumat beragama di Sulut dan Manado, bukanlah tanpa sebab. Hal itu merupakan kerja keras seluruh masyarakat Sulut yang ingin menjadikan daerah mereka rukun dan damai. Beberapa kali mereka mampu melewati ujian yang ingin merusak tatanan kerukunan umat beragama di daerah mereka. Sekitar 2001 dan 2002, misalnya, pasca konflik Ambon dan Poso, suasana di Sulut sempat mencekam, karena diterpa berbagai isu yang dapat melahirkan konflik antarumat beragama. Beruntung, reaksi cepat tokoh-tokoh agama, tokoh masyarakat, pemerintah setempat, masyarakat, dan aparat keamanan, dapat meredam berbagai ketegangan yang ditimbulkan oleh ulah provokator (Boroma, 2004: 106-107).

Pada tahun-tahun berikutnya, beberapa kali juga ada wacana yang mengancam kehidupan umat beragama di daerah ini. Isu yang paling mengemuka, ketegangan antara organisasi massa berbasis Kristen dengan pengurus Masjid Al-Khairiyah di Kawasan 45, Manado. Namun, kasus tersebut telah diselesaikan oleh masing-masing tokoh-tokoh agama, tokoh masyarakat, pemerintah kota, dan aparat keamanan, sehingga kerukunan antara umat
Kristen dengan Islam kembali harmonis (Syuhudi, 2015).

Merujuk pada fenomena kerukunan antarumat beragama di Manado yang tergolong baik berdasarkan riset di atas, bukan berarti hubungan internal di dalam satu kelompok agama berjalan mulus. Di dalam inter denominasi Kristen, misalnya, ternyata masih terdapat pertengkaran laten. Dari sekian denominasi dan organisasi gereja di Manado dan Sulut, denominasi Protestan dan Gereja Masehi Injil Minahasa (GMIM) adalah kelompok mainstream. Karena memiliki paling banyak anggota jemaat, GMIM terlihat mendominasi aspek ekonomi, politik, pemerintahan (birokrasi), dan sosial-kemasyarakatan. Adanya sikap dominan di segala bidang tersebut, akhirnya melahirkan berbagai prasangka negatif kelompok denominasi peripheral stream (arus pinggir) terhadap GMIM. Meski terkesan sembunyi-sembunyi dan tidak kelihatan di permukaan, tudingan "miring" pun bermunculan dari denominasi kecil yang dialamatkan kepada GMIM, seperti arogan dan menghegemoni.

Berdasarkan latar belakang di atas, tulisan ini mengajukan pertanyaan; bagaimana dinamika perkembangan denominasi Kristen di Manado, bagaimana bentuk pergulatan kepentingan politik dalam relasi inter denominasi Kristen di Manado, serta bagaimana kalangan inter denominasi Kristen mengatasi persoalan kepentingan yang terjadi di antara mereka. Selanjutnya, penelitian ini bertujuan untuk mendeskripsikan dinamika perkembangan denominasi Kristen di Manado, mendeskripsikan pergulatan kepentingan politik dalam relasi inter denominasi Kristen di Manado, serta mendeskripsikan kalangan inter denominasi Kristen mengatasi persoalan di antara mereka.

\section{Perspektif Teoritik \\ Denominasi Kristen}

Denominasi dalam tulisan ini merujuk pada penjelasan buku Jan S. Aritonang, "Berbagai Aliran di Dalam dan di Sekitar Gereja, Edisi yang Diperbarui" (2016), yang menyamakan denominasi sebagai aliran, supaya terkesan lebih netral. Aritonang juga menghindari penggunaan istilah 
sekta, sekte, dan bidat (untuk merujuk pada paham yang dianut gereje tertentu), dengan merujuk pendapat Dr. Peter Gowing, Dosen Sejarah Gereja di Filipina, yang menyatakan: "Dalam suasana dan upaya mewujudkan cita-cita oikumenis, istilah sekte dan bidat sudah tidak pada tempatnya untuk dipertahankan." Selanjutnya, dalam pandangan Aritonang, masing-masing aliran atau organisasi gereja berhak menilai aliran, gerakan atau organisasi gereja lain sebagai sekte dan bidat (Aritonang, 2016: $11)$.

Dalam konteks Manado, penyebutan aliran terkesan lebih familiar di kalangan Kristen daripada denominasi. Penyebutan istilah aliran sudah jamak terdengar di kalangan mereka, dan hal itu telah berlangsung dari generasi ke generasi. Sedangkan istilah denominasi hanya diketahui di kalangan tertentu, terutama di kalangan elite Kristen. Meski begitu, tidak ada yang mempersoalkan penggunaan kedua istilah tersebut (aliran atau denominasi), karena pemaknaannya dianggap sama dan tidak diskriminatif. Namun, untuk kepentingan tulisan ini, penulis lebih memilih menggunakan istilah denominasi, yang juga diartikan sama sebagai aliran.

\section{Relasi Kuasa}

Berbicara mengenai relasi kuasa tentu tak lepas dari Michel Foucault, seorang pemikir asal Perancis. Ia banyak mengulas relasi kuasa di dalam karya-karyanya, seperti Madness and Civilization, The Birth of Clinic, dan Discipline and Punish. Bagi Foucault, kekuasaan dan pengetahuan secara langsung saling menyatakan antara satu dengan yang lain. Tidak ada relasi kekuasaan tanpa dinyatakan dalam hubungannya dengan wilayah pengetahuan. Dengan kata lain, kekuasaan dan pengetahuan saling mengandaikan dan bertautan erat, serta menekankan kekuasaan dan proses historis (Aur, 2005: 151).

Cara pandang kekuasaan Foucault berbeda dengan Karl Marx. Marx melihat dan memahami kekuasaan hanya ada pada negara. Sementara Foucault memandang kekuasaan tidak mengacu pada satu sistem umum dominasi oleh suatu kelompok terhadap kelompok lain, melainkan ada beragam hubungan. Kekuasaan bagi Foucault bukanlah milik, melainkan strategi. Kekuasaan tidak datang dari luar, melainkan menentukan susunan, aturan-aturan, dan hubungan-hubungan dari dalam, dan memungkinkan semua itu terjadi. Kekuasaan selalu bertautan dengan pengetahuan.
Pengetahuan tidak berasal dari salah subjek yang mengenal, tetapi dari relasi-relasi kekuasaan yang menandai subjek tersebut. Meminjam istilah Francis Bacon, science is power, bahwa tidak ada pengetahuan tanpa kekuasaan, dan tidak ada kekuasaan tanpa pengetahuan. Hal ini menunjukkan, ada korelasi antara pengetahuan dan kekuasaan, yakni pengetahuan mengandung kekuasaan, sama halnya kekuasaan mengandung pengetahuan. Kekuasaan tidak selalu bekerja melalui penindasan dan represi, melainkan juga melalui normalisasi dan regulasi (Aur, 2015: 150-154).

Dengan demikian, bekerjanya kekuasaan ditandai oleh praktik-praktik sosial sejumlah pelaku dalam rangka proses pembentukan pengetahuan masing-masing, yang selanjutnya, sejumlah pelaku berkontestasi dan mengekspresikan tindakannya dalam bentuk saling mendukung, saling berjuang, saling bersaing, hingga saling menghancurkan (Irianto, 2015: 8).

\section{METODE PENELITIAN}

Jenis penelitian ini adalah kualitatif, dengan sasaran penelitian inter denominasi Kristen di Manado (Arikonto, 2002: 121-122). Penentuan informan dilakukan secara purposif, yakni menentukan orang-orang yang mengerti dan memahami tema penelitian ini (Kasniyah, 2012: 7). Untuk mendalami tema penelitian, dilakukan wawancara, observasi, dan studi dokumen. Mereka yang diwawancarai adalah beberapa tokoh Kristen, seperti pendeta, aktivis gereja, dan tokoh Kristen dari berbagai inter denominasi Kristen. Observasi dilakukan dengan melihat dari dekat sejumlah aktivitas, seperti relasi antar inter denominasi serta dunia perpolitikan di Manado. Studi dokumentasi dilakukan untuk memperkuat temuan data lapangan penelitian ini.

Analisis dilakukan secara deskriptif dan kritik. Setelah data dikumpulkan dari hasil wawancara sejumlah informan, observasi, dan studi dokumen, maka selanjutnya data tersebut direduksi, dipaparkan, dan diverifikasi (Endraswara, 2006: 176). Analisis data tidak hanya dijelaskan dengan menggunakan kalimat-kalimat yang dideskripsikan, tetapi juga sebisa mungkin memberi penjelasan mengenai objek penelitian (Moleong, 2000: 36).

\section{PEMBAHASAN \\ Dinamika Kemunculan Denominasi di Manado}

Tulisan ini tidak membahas periodisasi para misionaris melakukan penyebaran Kristen di Tanah Minahasa beberapa abad lalu. Kalaupun nanti 
disinggung, itu hanya sekadar mengingat, bahwa telah terjadi peristiwa penting pada tahun-tahun itu.

Aroma reformasi yang mulai dihembuskan pada 1998 menyebabkan keran demokrasi di Indonesia terbuka lebar. Kebebasan mengeluarkan pendapat dan mendirikan organisasi, dirayakan di mana-mana. Aktivitas yang ketika di masa Orde Baru seringkali mendapat larangan dan tantangan keras, kini seolah-olah tak terbendung, dan menjadi "tumpah-ruah". Berbagai denominasi di dalam Kristen di Kota Manado mulai marak bermunculan pasca reformasi bergulir, tepatnya awal 2000-an. Lajunya juga sulit terbendung. Terlebih lagi, di antara sesama Kristen tidak ada larangan secara formal untuk mendirikan denominasi yang berbeda dari denominasi yang telah ada sebelumnya. GMIM sebagai denominasi mainstream juga tidak mengeluarkan surat pernyataan resmi untuk melarang kehadiran denominasi baru di daerah ini.

Kemunculan denominasi dan organisasi gereja di Manado dapat dibagi dua fase. Fase pertama terjadi sekitar 1930-an hingga 1960-an, sedangkan fase kedua, setelah reformasi bergulir (awal 2000-an).

\section{Fase Pertama: 1930 hingga 1960-an;}

Pada 1929, denominasi Pantekosta sebenarnya telah ada di Sulut, dan saat itu mereka disebutPinksterbeweging. Ketika kali pertama muncul, kehadiran pemeluk Pantekosta saat itu dipandang oleh orang-orang Protestan Minahasa dan Belanda sebagai "liyan", diperlakukan diskriminatif, serta teralienasi dari kehidupan sosial. Maklum, selain masa itu adalah masamasa keemasan, di mana aroma kolonial Belanda masih kental mencengkeram Indonesia. Juga, kehadiran gerakan Pantekosta di Tanah Minahasa diketahui ingin merebut anggota jemaat Protestan, dan sikapnya yang terkesan ekslusif di tengah masyarakat. Atas sikapnya itu, sehingga orangorang Minahasa Prostestan, terlebih lagi Protestan merupakan denominasi mainstream, kemudian memberikan pelabelan (stigma) buruk terhadap orang Pantekosta (Wawancara beberapa informan di Manado, Maret 2018).

Sikap resistensi orang Minahasa Kristen (Protestan) terhadap orang Pantekosta, sama persis seperti dituangkan Aritonang, saat menggambarkan kemunculan Pantekosta di Indonesia sekitar 19131923, yang mendapat respon negatif masyarakat luas. Musababnya, kata Aritonang, penganut
Pantekosta dipandang fanatik (malah cenderung kurang waras), merasa benar sendiri, ajarannya sesat, emosinya kelewat meluap-luap dan tidak stabil, dan suka mencuri "domba dari kandang orang lain" (mencuri anggota jemaat). Kalangan Pantekosta juga dianggap sering mencela masyarakat luas di sekitar mereka sebagai jahat, penuh permusuhan, tersesat, dan tanpa harapan. Sikap yang terkesan ekslusif tersebut, menyebabkan mereka terasing dari pergaulan antargereja. Yang mula-mula tertarik dengan Pantekosta adalah golongan IndoEropa, yang selama ini kurang mendapat perhatian dari gereja mereka, dalam hal ini Indische Kerk, antara lain, disebabkan status sosial dan hukum mereka yang serba tanggung (bukan Eropa dan bukan pribumi), masyarakat Tionghoa, dan sukusuku pribumi yang sudah ataupun belum Kristen (Aritonang, 2016: 224-228).

Berdirinya GMIM di Minahasa pada 1934, tak bisa dilepaskan dari jasa-jasa kolonial. Bahkan, Ketua Sinode pertama hingga keempat GMIM adalah orang-orang Belanda. Nanti pada Ketua Sinode kelima GMIM, barulah dijabat pendeta asal Minahasa, A.Z.R Wenas. Sebelum berdiri GMIM, orang-orang Kristen di Minahasa melakukan peribadatan di Indische Kerk, atau yang diartikan Aritonang sebagai Gereja Protestan Indonesia (Aritonang, 2016: 224), yang berdiri sejak awal abad 20 di Tanah Minahasa. Indische Kerk-lah yang di kemudian hari bertransformasi menjadi GMIM. Setelah perang kemerdekaan pecah, rakyat Minahasa melakukan perlawanan terhadap Belanda. Termasuk, menginginkan berdirinya sebuah gereja otonom, mandiri, dan tanpa intervensi Belanda. Maka, rakyat Minahasa kemudian mendirikan Kerapatan Gereja Protestan Minahasa (KGPM) pada 1933, dan menjadikan KGPM sebagai basis perjuangan dan perlawanan rakyat Minahasa terhadap Belanda. KGPM juga tercatat gereja tertua di Sulut. Pada 1934, atau setahun setelah berdirinya KGPM, Belanda lalu mengubah nama Indische Kerk menjadi GMIM, yang dimaksudkan untuk menarik simpati rakyat Minahasa. Transformasi Indische Kerk menjadi GMIM, sebenarnya salah satu strategi Belanda untuk mengadu domba sesama orang Minahasa (Wawancara beberapa informan di Manado, Februari - Maret 2018).

GMIM yang beraliran Protestan sejak berdiri hingga sekarang menjadi gereja yang paling banyak menyedot anggota jemaat. Hingga 2017, berdasarkan data di Bidang Urusan Kristen Kanwil Kementerian Agama Sulut, jumlah jemaat GMIM 
tercatat sebanyak 846.274 jiwa di Sulut. Dengan jumlah jemaat seperti itu, tak mengherankan GMIM menjadi gereja mainstream. Jemaat GMIM pula yang kemudian mendominasi posisi-posisi elite di Manado dan Sulut, seperti politik, birokratpemerintahan, dan ekonomi (bisnis).

Setelah lima tahun Indonesia merdeka, Pantekosta akhirnya mulai berkembang luas di masyarakat Sulut sekitar tahun 1950. Perlahanlahan, kehadiran mereka juga diakui, dan mendapatkan perlakukan sama seperti jemaat GMIM, yang sejak dulu hingga kini mencatatkan diri jemaat mainstream di Sulut. Berdasarkan anggota jemaat di Sulut, Gereja Pantekosta di Indonesia Pantekosta (GPdI), merupakan terbesar kedua di bawah GMIM. Menurut Dosen STAKN Manado, sekaligus tokoh Pantekosta di Manado, Dr. Art Thomas, anggota jemaat Pantekosta di Sulut hingga 2018 berjumlah 250 ribu orang.

Selain Pantekosta, gereja yang juga hadir pada dekade 1950-an di Manado adalah, Christian Missionary Alliance, yang merupakan gereja dari Makassar. Pada 1954, diresmikan perkumpulan sebagai tempat ibadah ataupun untuk tujuan sosial dari Bala Keselamatan. Sebenarnya, sejak awal 1950-an, organisasi gereja ini mulai berkembang dan aktif melakukan kegiatan di Manado, dan dikenal dengan sebutan Korps Manado. Di samping penyebaran ajarannya, mereka juga aktif melakukan kegiatan sosial. Selanjutnya, pada 1960-an, Gereja Kristus Bethel, yang mayoritas jemaatnya beretnis Tionghoa berdiri di Manado. Sejak awal berdiri, gereja ini menggunakan bahasa Tionghoa sebagai bahasa utama dalam kegiatankegiatan ibadahnya (Makkelo, 2010: 158). Pada awalnya, orang Tionghoa Kristen (Protestan) itu, kerap mengikuti peribadatan di gereja GMIM. Namun, karena di antara mereka saat itu masih ada yang belum paham berbahasa Indonesia, mereka lalu meminta izin kepada pendeta GMIM untuk mendirikan gereja baru buat komunitas mereka, yang menggunakan Bahasa Tionghoa (Wawancara Sekretaris Departemen Misi dan Oikoumene Sinode Am Gereja-gereja di Suluttenggo, Deeby Momongan, di Manado, Maret 2018).

Gerakan Kharismatikikut merambah Manado sejak 1965. Awalnya, gerakan Kharismatik tidak mempunyai rencana mendirikan gereja baru, dan tetap berada dalam lingkup GMIM. Namun, pada perkembangan selanjutnya, mereka mendirikan gereja baru, yaitu Gerakan Injil Anugerah (Makkelo, 2010: 158).
Fase Kedua: Awal-awal 2000-an (Pasca Reformasi);

Kota Manado sempat dikejutkan dengan kehadiran sebuah kelompok "Pemuja Setan" (The Satanic Church) pada 1999. Dengan mengamati Manado sebagai wilayah terbuka yang memungkinkan tumbuh dan berbiak berbagai keyakinan, kelompok ini kemudian ingin menjadikan Manado sebagai markas pusat The Satanic Church di Asia. Empat tahun sebelumnya, yaitu sekitar 1995, sebelum adanya penolakan terang-terangan terhadap kelompok ini, mereka sebenarnya berhasil masuk dan punya pengikut (walau masih dalam hitungan jari), yang tersebar di berbagai kelurahan di Manado. Secara teologis, semua tokoh gereja di Manado menyatakan, The Satanic Church adalah ajaran sesat dan membahayakan. Ajaran-ajaran dan ritualnya dianggap menyimpang, dan tidak seperti diajarkan di dalam Al Kitab, seperti pengorbanan manusia, meniadakan ikatan keluarga, menganjurkan hubungan seks dengan siapa saja tanpa ikatan apapun, serta mengisap darah manusia (Makkelo, 2010: 153, dan wawancara beberapa informan di Manado, Maret 2018). Karena itu, kelompok ini mendapat penolakan di kalangan Kristen.

Sejak reformasi bergulir, denominasi di Manado (dan Sulut), mulai ramai bermunculan. Namun, akar kemunculan denominasi ini pada awal-awal 2000-an sebenarnya mengikuti jejak dari tahun 1960 - 1970-an, di mana saat itu denominasi mulai banyak bermunculan. Pada fase kedua ini, yang menjadi pimpinan dari denominasi baru kebanyakan orang-orang lokal (tempatan), yang memilih memisahkan diri dari organisasi gerejanya, karena mengalami kekecewaan terhadap pengelolaan gereja. Meski kecewa, mereka tidak langsung pindah ke denominasi baru, melainkan mulai tidak aktif sebagai anggota jemaat. Selanjutnya, mereka mencari informasi tentang denominasi lain di luar Sulut, yang menurutnya tepat sesuai harapannya. Pada umumnya, mereka meninggalkan Manado menuju Pulau Jawa (Jakarta dan Jawa Timur), dan setelah bertahun-tahun "berguru" di Jawa, orang-orang ini kemudian balik ke Manado, dan membuka denominasi baru, atau membuka cabang denominasi baru yang belum ada di Manado.

Para pendatang yang kerap disebut-sebut "membuka" denominasi baru di Manado pada awalawal 2000-an berasal dari Surabaya, Jawa Timur, dan beretnis Tionghoa, yang "menginjakkan" kaki di Manado untuk urusan kegiatan ekonomi (bisnis) 
dan keagamaan. Setelah merasakan terbuka peluang membentuk sebuah denominasi lain, mereka lalu menjalin relasi dengan orang-orang lokal, yang tertarik bergabung dengan mereka. Sebagian besar orang-orang lokal yang tertarik pindah denominasi atau gereja adalah mereka yang kecewa terhadap pengelolaan internal gereja sebelumnya, dan persoalan liturgi.

Sebagai gereja mainstream, GMIM melihat fenomena kemunculan beragam denominasi di Manado sebagai sesuatu yang lumrah. Pendeta GMIM, yang juga mantan Sekretaris Sinode GMIM, Dr. Nico Gara, menyatakan, sepanjang kehadiran orang atau kelompok tersebut tidak mengganggu dan tidak mengancam kerukunan antarumat beragama, tidak ada alasan untuk melarang atau menghalang-halangi kelompok tersebut beribadah. Menurut Nico, yang juga mantan Ketua Forum Kerukunan Umat Beragama (FKUB) Sulut dua periode, melarang orang atau kelompok agama untuk beribadah sesuai kepercayaan dan keyakinan bertentangan dengan Undang-Undang Dasar 1945 Pasal 29. Kemunculan berbagai paham keagamaan dan denominasi bisa diterima dengan tangan terbuka, sepanjang kehadiran mereka tidak mengganggu substansi kultural. Misalkan, bila kehadiran kelompok itu bisa menimbulkan keresahan, perasaan tidak nyaman, dan prasangka buruk masyarakat, tentu saja mereka akan mendapat penolakan, seperti halnya The Satanic Church, yang ajaran dan doktrinnya dianggap tidak sejalan dengan nilai-nilai ajaran Kristen (Wawancara Nico Gara, di Manado, Februari 2018).

Kemunculan beragam denominasi di Manado disebabkan oleh beberapa hal. Antara lain, kisahkisah sejarah yang panjang (historisitas), perbedaan menafsir Alkitab, perbedaan menerapkan tata ibadah, perbedaan metode pekabaran Injil, serta sikap terbuka pemerintah setempat yang tidak melarang dan membatasi setiap denominasi yang akan hadir di daerah ini. Malah, dalam setiap kali kesempatan, pemerintah justru memberikan dukungan dan apresiasi dengan menghadiri undangan mereka, meskipun berbeda denominasi dengan pemerintah (Makkelo, 2010: 155). Ada juga pendapat lain menyatakan, perpindahan jemaat gereja ke denominasi lain disebabkan oleh kekecewaan anggota jemaat terhadap pengelolaan gereja, dan bahkan, melebar sampaike permasalahan perbedaan pandangan politik, serta perebutan sumber-sumber ekonomi (Wawancara Antropolog dan Sejarawan Universitas Sam Ratulangi Manado,
Nono Sumampouw, dan Roger Kembuan, serta aktivis GMIM, Anggie Wuysang, di Manado, Maret 2018).

Kehadiran kelompok Saksi Yehova di Manado sempat pula "mencuri" perhatian dan menghebohkan kalangan Kristiani. Masih membekas dalam ingatan orang Manado, bahwa pada 1976, pemerintah sempat menyatakan kelompok ini sesat, berdasarkan SK Jaksa Agung RI No. Kep. 129/JA/12/1976 tanggal 7 Desember 1976, yang menyatakan larangan atas kelompok ini untuk melakukan kegiatan di Indonesia. Bersama pimpinan organisasi agama atau gereja-gereja resmi, negara berpendapat, kelompok ini telah menyebarluaskan ajaran sesat yang menimbulkan keresahan dan gangguan dalam masyarakat dan bisa merusak kehidupan beragama di Indonesia (Aritonang, 2016: 394). Sementara, pada 1 Juni 2001, pemerintah RI melalui Jaksa Agung Marzuki Darusman mengeluarkan SK No. Kep. 255/A/ JA/06/2001, yang isinya membatalkan SK Jaksa Agung RI No. Kep. 129/JA/12/1976 tanggal 7 Desember 1976, lantaran tidak sesuai prinsipprinsip Demokrasi. Pada SK baru tersebut (2001), dinyatakan, "Kepada Ajaran/Perkumpulan Siswasiswa Alkitab/Saksi Yehova diperbolehkan hidup beraktivitas berdampinan bersama ajaran/aliran keagamaan lainnya yang sah di Indonesia, kecuali apabila di kemudian hari terhadap pelanggaran terhadap peraturan perundang-undangan yang berlaku, Surat Keputusan ini akan ditinjau kembali" (Aritonang, 2016: 395-396).

Kelompok Saksi Yehova diperkirakan masuk ke Manado sekitar 2003. Jumlah pengikutnya hingga kini berkisar seratusan orang. Kehadiran mereka juga terlihat tidak begitu menonjol dibanding denominasi lain di Manado. Bahkan, meski dalam pergaulan mereka bisa membaur, sebagian besar penganutnya terkesan tertutup menyangkut teologisnya. Saat ini, mereka punya satu tempat ibadat bernama Balai Kerajaan Saksi-Saksi Yehova.

Di Manado, masih jamak ditemui orangorang Kristen menyebutkan diri mereka "Kristen Protestan". Tampaknya, penyebutan Protestan ini, sekaligus juga sebagai penanda, bahwa mereka sebenarnya dominan. Meski begitu, ada juga denominasi lain, seperti, antara lain, Pantekosta, Advent, Kharismatik, dan Bala Keselamatan, dan Saksi Yehova.

\section{Organisasi Gereja di Sulut}

Merujuk data Bidang Urusan Kristen Kanwil Kemenag Sulut, organisasi gereja di Sulawesi 
Utara berjumlah 76 buah. Di antara organisasi gereja tersebut, yang terbanyak memiliki anggota jemaat adalah GMIM. Dari 571 gereja di Manado (BPS Kota Manado, 2017), jumlah jemaat (gereja) GMIM terhitung paling banyak; sekitar 200 jemaat. Sisanya, gereja-gereja dari denominasi lain, seperti Pantekosta, Advent, Kharismatik, Bala Keselamatan. GMIM juga tercatat memiliki anggota jemaat paling banyak di Manado. Sedangkan di Sulut, anggota jemaat GMIM sampai 2016 terhitung 846.274 jiwa, dan termasuk paling banyak di Sulut (Wawancara, Kepala Bidang Urusan Kristen Kanwil Kemenag Sulut, Jiffry Kawung, di Manado, Februari 2018).

\section{Relasi Inter Denominasi yang BelumAkur}

"Torang kwa nyanda suka dorang batampa pa torang pe kintal. Mar, karna dorang so di sini katu', jadi torang nimbole mo bekeng apa-apa. Nyanda mungkin le torang mo larang deng suru dorang pigi."

(Kami sebenarnya tidak senang mereka (denominasi lain) tinggal di lingkungan kami. Tapi, karena mereka sudah ada di sini, jadi mau diapa lagi. Tidak mungkin kami melarang, dan menyuruh mereka pergi)

(Wawancara, Kr, di Manado, Maret 2018).

Apabila melihat kutipan di atas, nampak ada yang belum "beres" dengan relasi inter personal denominasi di Manado. Pernyataan di atas adalah representatif dari sebagian besar orang Kristen di Manado, yang lebih senang bertempat tinggal di lingkungan yang penduduknya berasal dari satu denominasi.Untuk kondisi sekarang ini, sangat sulit menemukan sebuah kompleks perumahan, atau perumahan penduduk, yang semua penghuninya terdiri atas satu agama, atau satu denominasi. Yang kini banyak ditemui, satu kompleks perumahan, atau perumahan penduduk, dihuni oleh mayoritas dari kelompok agama atau denominasi tertentu. Di perumahan penduduk di Lingkungan Ares, Kecamatan Tikala, Manado, misalnya. Di sini, mayoritas pendudukmemeluk Kristen, dan tercatat sebagai anggota jemaat GMIM, dan juga penduduk beragama lain (Muslim dan Katolik), serta denominasi lain (Pantekosta dan Kharismatik). Di perumahan ini pula terdapat satu keluarga yang berasal dari denominasi Saksi Yehova.

Bagi GMIM, kehadiran penganut Saksi Yehova dipandang "the other". Pandangan tersebut mewakili juga pandangan denominasi lain, seperti Pantekosta,Advent, Bala Keselamatan, dan Kharismatik. Semua informan yang saya temui masih memandang Saksi Yehova sempalan, dan bukan bagian Kristen. Ajaran mereka dianggap berbeda dengan ajaran-ajaran Kristen.Secara personal, penganut Saksi Yehova sebenarnya terkesan menutup diri. Tidak seperti denominasi lain yang terbuka, golongan Saksi Yehova jarang memperkenalkan diri secara terbuka mengenai denominasinya kepada orang-orang. Biasanya, orang-orang luar baru mengetahui denominasi yang mereka anut setelah mendapatkan "bisikbisik" dari tetangganya. Dalam pengamatan saya dengan penganut Saksi Yehova di beberapa tempat di Manado, saya melihat mereka memang bergaul akrab dengan tetangga di sekitar tempat tinggalnya, atau orang-orang dari denominasi lain di luar lingkungan tempat tinggalnya. Relasi yang dibangun itu, sebenarnya sebagai upaya agar kelompok mereka dapat diterima di lingkungan tempat tinggalnya (survive).

Berbeda dengan personal Saksi Yehova yang cenderung tak ingin diketahui identitasnya oleh orang di luar mereka. Pendeta di kalangan Saksi Yehova terlihat justru sebaliknya, yakni terbuka. Sampai penelitian ini tuntas, mereka masih sering melakukan khutbah dari rumah ke rumah (home to home) penduduk dengan tujuan menarik simpatik, sekaligus merekrut anggota jemaat baru. Biasanya, mereka mendatangi rumah penduduk seorang diri atau berkelompok (hingga tiga orang). Mereka seolah tak kenal lelah memperkenalkan ajaran mereka kepada masyarakat, terutama di kalangan Kristen.

Aktivitas Saksi Yehova tersebut dianggap mengganggu kenyamanan kalangan Kristen, terutama yang rumahnya pernah dikunjungi. Terlebih, beredar di kalangan Kristen, bahwa apa yang dilakukan Saksi Yehova itu, merupakan upaya untuk merekrut anggota jemaat baru. Meski begitu, orang Kristen tidak melarang, apalagi mengusir dengan cara-cara kasar. Bila ada orang Saksi Yehova yang ingin berkhutbah di rumah mereka, tuan rumah biasanya akan menolak dengan cara-cara "halus" untuk menghindari saling ketersinggungan.

Pertengkaran inter denominasi sejauh ini disebabkan oleh persoalan interpretasi teologis, pernikahan, perebutan jemaat, dan pendirian gereja. Dampak dari semua itu kerap memengaruhi relasi inter personal antardenominasi hingga relasi keluarga atau kerabat kedua belah pihak. Yang pertama adalah persoalan teologis. Denominasi 
yang sering berdebat soal teologis adalah Protestan (dalam hal ini, GMIM) dengan Pantekosta dan Kharismatik. Titik pertengkaran mereka adalah adanya klaim kebenaran (truth claim) tentang pembaptisan dan tata cara beribadah, yang samasama menganggap sesuai ajaran Alkitab.

Menurut GMIM, pembaptisan dilakukan sejak masih bayi, sedangkan Pantekosta dan Kharismatik pembaptisan dilakukan pada saat seseorang mencapai usia dewasa atau akil baligh. Tata cara pembaptisan pun berbeda, yaitu GMIM memercikkan air, sedangkan Kharismatik memasukkan orang yang akan dibaptis ke dalam kolam (Selam). Pada tataran tertentu, perbedaan teologis ini terkadang pula ikut memengaruhi relasi individual,dan bahkan sesekali relasi sosial. Salah satu contohnya, pemberian stigma denominasi GMIM,Pantekosta, Advent, terhadap ajaran Saksi Yehova, meski secara individual, mereka (personal) bergaul dengan penganut Saksi Yehova di lingkungan tempat tinggalnya.

Kedua, pernikahan beda denominasi juga kerap mengundang pertengkaran antarkeluarga kedua belah pihak, dan berujung kepada inharmonis. Seorang informan perempuan menyatakan, ia dulu sempat nyanda diajak omong (tidak diajak berbicara) oleh orang tua selama beberapa bulan, karena menikah dengan orang yang berbeda denominasi. Orang tua baru mengajak berbicara setelah anak pertamanya lahir, dan suami mengikuti atau pindah ke denominasinya. Kendati pernikahan beda denominasi sering menjadi pertentangan keluarga kedua belah pihak, namun fenomena tersebut masih sering terjadi sampai saat ini. Alhasil, yang banyak terjadi, bukan lagi komunitas interdenominasi yang saling berhadap-hadapan, melainkan para keluarga dan kerabat kedua belah pihak akibat pernikahan beda denominasi tersebut.

Ketiga, perebutan anggota jemaat juga dapat menyebabkan relasi inter denominasi menjadi tidak akur. Dalam hal ini, GMIM sering menuding Pantekosta dan Kharismatik mengambil anggota jemaat mereka. Di Manado, masalah perebutan jemaat merupakan hal sensitif, dan bisa membuat pihak gereja merasa tersinggung. Tarik menarik jemaat inilah, sehingga relasi sosial antara GMIM, Pantekosta, Kharismatik, Bala Keselamatan, sewaktu-waktu bisa menegang, terutama di kalangan para elite gereja. Menurut pengamatan tokoh muda GPdI di Manado, Steven Sumolang, anggota jemaat GMIM secara kuantitas memang terlihat lebih banyak hengkang ke denominasi lain.
Terakhir, atau keempat adalah, pendirian gereja inter denominasi. Sejak dekade 1980-an hingga 2000-an, masih terlihat adanya pelarangan berdiri sebuah gereja tertentu. Di beberapa kabupaten, misalnya, ada sebuah perkampungan yang mayoritas penduduknya beribadat di KGPM, dan melarang gereja lain berdiri di situ, sehingga 100 persen penduduk di situ KGPM. Sebaliknya, di sebuah perkampungan lain, yang mayoritas penduduknya GMIM, juga melarang berdiri gereja dari denominasi lain di lingkungan tinggal mereka. Bahkan, orang-orang GMIM melarang mendirikan Gereja GPdI Pantekosta di Desa Kali, Pineleng, Kabupaten Minahasa. Pada saat sementara membangun gereja, warga masyarakat GMIM yang tinggal di sekitar situ, melempari gereja dengan batu. Pendeta GPdI malah sempat berkelahi. Gereja tersebut sekarang ini digunakan beribadah, meski bangunan gedungnya belum sepenuhnya terbangun (Wawancara beberapa informan di Manado, Maret 2018).

Toleransi dalam internal Kristen Manado masih bisa tertutupi dengan mengatasnamakan "hidup bertetangga", dan hubungan pertemanan. Jadi, dalam konteks Manado, toleransi erat kaitannya dengan sikap individual seseorang. Meski terjadi "keributan" interdenominasi, sebagian besar di antara mereka tidak ingin melibatkan diri. Karena itu, mereka menyerahkan sepenuhnya kepada personal masing-masing, dan mengambil sikap menghindari keributan. Ini juga menunjukkan, bila tidak menyukai sesuatu, kalangan Kristen cenderung menyembunyikan ketidaksenangannya, cuek, masa bodoh, serta menghindari ribut-ribut.

\section{GMIM dalam Panggung Politik}

Adanya dominasi salah satu denominasi terlihat jelas dalam panggung politik dan birokrasi pemerintahan. Dominan GMIM sebagai anggota jemaat terbanyak di Manado (dan Sulut), mewarnai hampir semua jabatan penting dan strategis di politik, birokrasi, hingga organisasi massa. Di posisi manapun, baik politik maupun birokrat, selalu saja ada anggota jemaat GMIM. Gubernur dan Wakil Gubernur Sulut periode 2015 - 2020, Olly Dondokambey dan Steven Kandouw, adalah anggota jemaat GMIM. Demikian pula, Wali Kota Manado, Vicky Lumentut, yang selain anggota jemaat GMIM, juga menjabat Ketua Kaum Bapa GMIM. Sementara Ketua Ketua Pelayanan Wanita, atau Ketua Kaum Ibu GMIM, dipegang adik kandung Gubernur Sulut sekarang, Adriana Dondokambey, yang juga anggota DPRD Sulut. 
Kaum Bapa/Ibu bukanlah dari kalangan pendeta, melainkan kalangan awam.

Membaca GMIM terkait konteks politik di Manado dan Sulut erat kaitannya dengan politik lokal. Ketika anggota jemaat GMIM mencalonkan diri dalam pemilihan kepala daerah (pilkada) atau calon anggota legislatif (caleg), hampir semua anggota jemaat memilih kandidat bakal calon (balon) tersebut. Sejauh ini, anggota jemaat GMIM selalu terlihat satu suara memilih kandidat balon asal GMIM. Namun, tentu saja, itu tidak berlaku bila balonnya sama-sama berasal dari anggota jemaat GMIM. Ketika Pilkada Walikota Manado 2016-2021, Vicky Lumentut diuntungkan, karena memilih wakilnya, Mor Dominus Bastiaan, dari denominasi Pantekosta, sehingga meraih suara terbanyak dari anggota jemaat GPdI. Sementara lawannya, ada yang berpasangan dengan sesama GMIM, dan dengan Muslim, sehingga suara mereka akhirnya terbelah (Wawancara beberapa informan di Manado, Maret 2018).

Tulisan ini menitikberatkan pada masalah politik, karena hampir semua dimensi kerap dikait-kaitkan dengan politik. Jabatan kepala dinas sampai penatua, misalnya, adalah politis. Jabatan penatua dan syamas di setiap kolom (satu kolom terdiri atas 15 sampai 25 kepala keluarga) jemaat GMIM dipegang oleh sebagian besar pegawai negeri. Penatua bertugas mengurus ibadah-ibadah, khutbah-khutbah, dan menjaga keimanan anggota jemaat supaya tidak pindah denominasi. Sedangkan syamas bertugas mengurus masalah keuangan (bendahara). Penatua juga berperan membantu mencari dukungan suara dari anggota jemaatnya.

Sekaitan anggota jemaat GMIM yang terjun ke politik dipandang sebagai sesuatu yang lumrah, dan tak bisa dihindarkan. Menjadi politisi adalah hak dan pilihan individual. Bagi kalangan GMIM sendiri, fenomena ini sering menjadi bahan pembicaraan anggota jemaat lainnya. Mereka menyayangkan, "GMIM dijadikan alat tunggangan politisi.” Secara kelembagaan, Sinode GMIM belum pernah mengeluarkan keputusan resmi untuk memberikan dukungan kepada salah satu calon di ajang pilkada dan caleg. Begitupula, GMIM belum pernah mengeluarkan larangan resmi terhadap orang-orang yang ingin "memanfaatkan" anggota jemaat untuk kepentingan pilkada dan caleg. Hal tersebut merupakan "kreativitas" bakal calon (balon) dan tim sukses untuk mempengaruhi anggota jemaat lain. Namun, mencari dukungan anggota jemaat selalu dilakukan di luar jemaat (gereja). Meski begitu, bukan hanya jemaat GMIM yang bermain politik, melainkan juga hampir semua anggota jemaat gereja pada denominasi lain (Wawancara beberapa informan di Manado, Maret 2018).

Pertarungan memperebutkan jabatan "kosong satu" di dunia birokrasi kerap juga dikaitkan dengan agama. Pergantian Kepala Kantor Wilayah (Kakanwil) Kementerian Agama (Kemenag) Sulut selalu menjadi isu hangat. Selama ini, Kakanwil Kemenag selalu ditepegang oleh Muslim. Sebagai daerah yang kebanyakan penduduknya Kristen, umat Kristen menginginkan Kakanwil Kemenag Sulut dijabat dari kalangan mereka sendiri (Kristen), seperti di daerah lain, yang menjadi kelompok mayoritas. Misalkan, Kakanwil Kemenag di Papua adalah orang Kristen, dan Kakanwil Kemenag di Nusa Tenggara Timur beragama Katolik. Ketika terjadi pergantian Kakanwil Kemenag Sulut pada Januari 2018, dan jabatan tersebut lagi-lagi dipegang orang Islam, ratusan orang Kristen dari berbagai Lembaga Swadaya Masyarakat menggelar aksi unjuk rasa. Pengunjuk rasa memulai aksinya dari Kantor DPRD Provinsi Sulut, lalu ke Polisi Daerah Sulut, dan berakhir di Kantor Kemenag Sulut, Jalan 17 Agustus Manado. Pengunjuk rasa menuntut Kakanwil Kemenag Sulut dijabat orang Kristen.

Aksi demonstrasi penolakan Kakanwil Kemenag Sulut dijabat orang non Kristen, bukanlah kali pertama terjadi. Kejadian seperti ini selalu berulang, terutama menjelang pergantian jabatan "kosong satu" di Kemenag Sulut itu. Namun, aksi unjuk rasa selalu berjalan tertib dan damai. Aksi ini juga semata-mata ingin menyuarakan aspirasi orang-orang Kristen yang menginginkan jabatan Kakanwil Kemenag Sulut dipegang orang Kristen. Jabatan Kakankemenag Kota Manado sendiri, yang selalu dijabat orang Islam, hampir tidak pernah mendapat penolakan atau aksi unjuk rasa.

Anggota jemaat gereja banyak pula berkiprah di organisasi massa. Organisasi massa yang paling berpengaruh di Manado dan Sulut adalah, Brigade Manguni Indonesia (BMI). Dari sekian organisasi massa di Manado dan Sulut, jumlah anggota BMI yang didirikan pada 2002 terhitung paling banyak. Ia tidak hanya tersebar di Manado dan Sulut, melainkan juga di daerah lain, termasuk mancanegara (Syuhudi, 2016: 61-62). BMI juga sering terlibat politik praktis, yang mendukung salah satu kandidat pada pesta pilkada maupun caleg. Setiap kali melakukan konvoi di jalanjalan, penampilan anggota BMI terkesan militan. 
Militansi di sini dimaknai sebagai orang yang berani dan rela mati demi menjaga daerahnya dan NKRI. Terlebih, pada awal 2000-an, konflik sering terjadi di Indonesia dan menelan korban jiwa (seperti Ambon dan Poso), dan dikhawatirkan merembes ke Sulut. BMI selalu menjadi garda terdepan untuk pengamanan dan tameng dari ulah oknum yang ingin membuat kekacauan di Manado dan Sulut. Awalnya, BMI dibentuk sebagai "Tentara Kristen" untuk menandingi kehadiran Laskar Islam, FPI. Tapi, karena kurang mendapat respek dari tokoh Kristen, BMI kemudian menamakan diri menjadi organisasi adat (Syuhudi, 2016: 9).

BMI sulit memisahkan diri dari identitas Kristen. Meskipun di dalam kepengurusan BMI terdapat juga penganut agama lain (seperti Islam), mayoritas anggota BMI adalah orang Kristen yang merupakan anggota jemaat GMIM. BMI pernah ikut menolak renovasi pembangunan Masjid AlKhairiyah di Perkampungan Texas, Manado. Selain BMI, ada juga beberapa organisasi massa lain berbasis Kristen, antara lain, Laskar Manguni (LM), Waraney Wuaja, Pisok, Milisi Waraney (pasukan perang dengan lambang Bintang Daud), dan Milisi Kristi, yang ikut mewarnai militansi Kristen.

Organisasi massa inilah yang kerap melakukan aksi-aksi demonstrasi di jalan. Namun, perlu digarisbawahi di sini, militansi tersebut tidak ada korelasinya dengan sinode gereja. Atau, dalam bahasa Pendeta GMIM, Nico Gara, orang Kristen yang senang ribut, berkelahi, dan tidak mencintai kedamaian dikategorikan "Kristen Abangan". Menurut Nico, orang-orang seperti ini belum mampu menyerap dan melaksanakan nilai-nilai Kasih Kristus yang mengasihi semua umat manusia. Meski berafiliasi ke salah satu denominasi, sikap militansi anggota jemaat yang masuk ke dalam salah satu kelompok identitas itu sifatnya personal, tidak mewakili gereja mereka.

Lalu, apa tanggapan denominasi "kecil" menghadapi dominasi GMIM pada pertarungan politik? Sebagai kelompok denominasi minoritas, mereka tentu kesulitan membendung kekuatan anggota jemaat GMIM. Denominasi kecil ini selalu berada di bawah "bayang-bayang" anggota jemaat GMIM. Untuk mendapatkan “jatah” kekuasaan, denominasi kecil pada umumnya bermain aman, dengan memosisikan diri sebagai pengikut. Mereka juga cenderung bersikap pasrah dan pasif, sembari menunggu pembagian "jatah", berupa jabatan di pemerintahan, di organisasi, pembagian proyek, dan sebagainya.

\section{PENUTUP}

Relasi inter antar denominasi di kalangan Kristen di Manado terlihat belum sepenuhnya akur. Mereka tampak rukun di permukaan saja disebabkan oleh kondisi sosial yang terkesan dipaksakan, karena "tidak mau ribut" dengan orang yang berbeda denominasi dengan mereka.Realitas ini sebenarnya cukup rawan, karena sewaktu-waktu bisa memicu lahirnya perseteruan di antara inter denominasi.

Perkembangan denominasi di Manado cukup berkembang, terutama pasca reformasi. Dari sekian banyak denominasi yang terdapat di Manado, denominasi yang paling banyak jumlah pemeluknya berasal dari Gereja GMIM, yang beraliran Protestan. Dengan demikian, jemaat GMIM pula yang kemudian terlihat paling banyak menduduki jabatan penting dan strategis di Sulut dan Manado.

Pada praktik di ranah sosial politik dan pemerintahan, misalnya, GMIM sebagai kelompok dominan terlihat mendominasi. Gubernur Sulut, Walikota Manado, dan sejumlah kepala dinas di instansi pemerintahan provinsi kota, dan kabupaten, tercatat sebagai jemaat GMIM. Begitupula yang duduk sebagai anggota dewan di tingkat provinsi, kota, dan kabupaten. Meski terkesan "samar", namun efek dari dominannya GMIM terlihat dengan membatasi akses kelompok agama dan inter denominasi untuk bisa sejajar dengan mereka di bidang politik, pemerintahan (birokrasi), dan sosial-kemasyarakatan. Sejauh ini, denominasi lain dan kelompok agama lain (non Kristen) "dipaksa"terlihat cenderung sebagai pengikut, dan berada di bawah bayang-bayang GMIM. Pada akhirnya, hal yang dilakukan denominasi kecil dan kelompok agama lain agar bisa mendapat akses ke dalam lingkaran kekuasaan adalah dengan cara bermain aman dan bersikap pasrah.

\section{UCAPAN TERIMA KASIH}

Tulisan ini tak akan terwujud apabila tidak mendapat bantuan dari berbagai pihak. Karena itu, penulis ingin mengucapkan terima kasih kepada informan yang telah membantu selama penelitian ini berlangsung. Mereka itu, antara lain, Mantan Sekretaris Umum GMIM, Pendeta Dr. Nico Gara, Direktur STAKN Manado, Dr. Art Thomas, Nono Sumampouw, MA, dan Hasanuddin Anwar, M.Si. Tak pula pula penulis ucapkan kepada Kepala Balai Penelitian dan Pengembangan Agama Makassar yang telah mensponsori penelitian ini, Tim Mitra 
Bestari serta jajaran redakasi Jurnal Al Qalam yang mengizinkan untuk memuat tulisan ini, serta berbagai pihak yang tidak bisa disebutkan satu per satu.

\section{DAFTAR PUSTAKA}

Aritonang, Jan S. 2016. Berbagai Aliran di Dalam dan di Sekitar Gereja (Edisi yang

Diperbarui). Cetakan ke-15. Jakarta. PT. BKK Gunung Mulia.

Arikunto, Suharsini, 2002, Prosedur Penelitian: Suatu Pendekatan Praktek, Jakarta:

Rineka Cipta.

Aur, Alexander, 2015, "Pascastrukturalisme Michel Foucault dan Gerbang Menuju

Dialog Antar Peradabanm", dalam Teori-Teori Kebudayaan, (ed.) Mudji Sutrisno dan Hendar Putranto, Yogyakarta: Kanisius.

Boroma. Suhendro. 2004. "Generasi Muda Mencegah Konflik: Pengalaman Sulawesi

Utara", dalam Meretas Dialog Membangun Kerjasama. Taufik Pasiak (ed). Manado.

BPS Kota Manado, 2016.

Endraswara, Suwardi, 2006, Metode, Teori, Teknik Penelitian Kebudayaan; Ideologi,

Epistemologi, dan Aplikasi, Yogyakarta: Pustaka Widyatama.

Irianto, Agus Maladi, 2015, Media dan Kekuasaan, Antropologi Membaca Dunia
Kontemporer, Cetakan Kedua Oktober, Semarang: Pustaka Mandiri.

Kasniyah, Naniek, 2012, Tahapan Menentukan Informan dalam Penelitian Kualitatif,

Yogyakarta: Penerbit Ombak.

Keputusan Bersama Menteri Agama dan Menteri Dalam Negeri Nomor 1 tahun 1979

tentang Tata Cara Pelaksanaan Penyiaran Agama dan Bantuan Luar Negeri kepada Lembaga Keagamaan di Indonesia.

Makkelo, Ilham Daeng. 2010. Kota Seribu Gereja, Dinamika Keagamaan dan

Penggunaan Ruang di Kota Manado. Yogyakarta. Ombak. Moleong, Lexi J, 2000, Metode Penelitian Kualitatif, Bandung: Rosda Karya.

Syuhudi, Muhammad Irfan. 2015. Penyuluh dan Pengelolaan Kerukunan di Manado.

Laporan Penelitian, Makassar: Balai Litbang Agama.

Syuhudi. Muhammad Irfan. 2016. "Geliat Politik Identitas di Kota Manado”. dalam

Jurnal Harmoni. Nomor 2 Volume 15, Mei - Agustus 2016. Jakarta: Badan Litbang dan Diklat Kemenag RI.

Syuhudi, Muhammad Irfan, 2016, Menguatnya Politik Identitas dan Dampaknya bagi

Kerukunan Umat Beragama di Kota Manado, Laporan Penelitian, Makassar: Balai Litbang Agama.

Tim Peneliti Balai Litbang Agama Makassar, 2011, Potret Kerukunan Umat

Beragama di Sulawesi Utara. Laporan Penelitian, Makassar. 